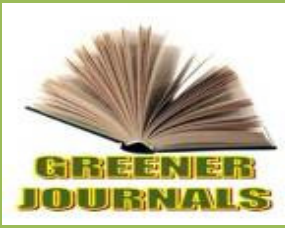

\title{
Studies on Growth Performance, Nutrient Utilization, and Heamatological Characteristics of Broiler Chickens Fed Different Levels of Azolla - Moringa Olifera Mixture
}

\author{
Alagbe JO
}

Dan-malafia Farms Limited, Ibadan.

Article No.: 081817107

DOI: 10.15580/GJAS.2017.6.081817107

\section{Submitted: $18 / 08 / 2017$}

Accepted: 22/08/2017

Published: 29/08/2017

*Corresponding Author

Alagbe $\mathrm{JO}$

E-mail: demsonfarms@yahoo.

com

\section{Keywords:}

broiler chickens, growth

performance, nutrient retention,

Moringa Oleifera
This study was conducted to examine the growth performance, nutrient utilization and haematological characteristics of broiler chickens fed diets supplemented with Azolla-Moringa Oleifera mixture. One hundred and sixty (160) Arbo-acre day old chick of mixed sex was divided into four groups with four replicates, each of ten birds in a completely randomized design. Treatment 1 was fed basal diet without Azolla -Moringa mixture (MLMAZP), treatment 2, 3 and 4 were fed basal diets supplemented with MLMAZP at levels 5, 10 and $15 \%$ respectively. Proximate analysis shows that Azolla powder contained $22.51 \%$ crude protein, $3.53 \%$ ether extracts, $14.13 \%$ ash, $18.15 \%$ crude fibre and $37.88 \%$ nitrogen free extract while Moringa Oleifera leaf meal contained $27.51 \%$ crude protein, $2.23 \%$ ether extracts, $7.13 \%$ ash, $19.25 \%$ crude fibre and $43.88 \%$ nitrogen free extracts. The basal diet was formulated to meet the nutritional requirements of broilers according to NRC (1994). The results shows that there was a significant $(P<0.05)$ difference in the final live weight, feed conversion ratio, carcass/dressing percentage and daily water intake. However, no significant influence $(P>0.05)$ were observed for feed intake and some of the hematological parameters measured (PCV, Hb, RBC, WBC, $\mathrm{MCV}, \mathrm{MCH}$ and $\mathrm{MCHC}$ ). No mortality was recorded throughout the experimental period which lasted for $\mathbf{4 2}$ days.

It can be concluded based on data from performance, nutrient utilization and hematological parameters that MLMAZP can be added up to $15 \%$ in the diets of broiler chickens. 


\section{INTRODUCTION}

There has recently been an increase in competition among ingredients used in the manufacture of livestock feed. There is consequently a great need for alternatives that can supply in the high demands for such ingredients, in particular for soya meal (Chisoro, 2015). Garba et al (2010) suggested partial or complete replacement of expensive and conventional feed ingredients with cheaper non-conventional substitutes. One of the ways of reducing the cost of production and making protein available to people in cheaper prices especially in developing countries is by the use of agricultural by-products and tropical plants (leaf meal) which are not directly used by humans as food to feed livestock (Asar et al., 2010). It has been reported that some leaf meal provides animals with necessary vitamins, minerals, oxycarotenoids and protein (Opara, 1996), for instance Moringa Oleifera leaves and pods are found to be loaded with vitamins and amino acids (Francis et al., 2005). Fuglie (2009) stated that the high bioavailability of Moringa leaves and stems makes them an excellent feed for livestock, it is an excellent source of sulphur containing amino acids, cysteine and methionine, which are often limiting in most feedstuff used for feeding animals (Maroyi, 2006).

Moringa Oleifera commonly known as drumstick -tree or horse radish tree is a multi -purpose that has given considerable fodder yield in the tropical humid forest zone of Nigeria during wet and dry seasons (Fadyimu et al., 2011). According to Onimisi et al (2007) Moringa Oleifera can be included up to $30 \%$ in rabbit diet without any adverse effect on the growth performance. It can also be included up to $20 \%$ in the diets of laying birds without any adverse effect on their production and performance (Kakengi et al. 2007). Moringa leaf meal contains $27.51 \%$ crude protein, $19.25 \%$ crude fibre, $2.23 \%$ crude fat, $7.13 \%$ ash, $76.53 \%$ moisture, $43.88 \%$ carbohydrate and $1296.00 \mathrm{Kj} / \mathrm{g}$ calories (Oduro et al., 2008).

Azolla is an aquatic fern belonging to the family Azollaceae and order Pteridophyta. It grows naturally in stagnant water of drains, canals, ponds, rivers and marshy lands. According to Biplob et al (2002) six species of azolla are found in tropics and sub tropics, it is an unconventional potential feed ingredient for broilers (Pannerker, 1988). Azolla abhors symbiotic blue green alga (Anabaena azollae) which is responsible for the fixation of atmospheric nitrogen inform of protein. Azolla is rich in essential amino acids, proteins, vitamins (vitamin A, vitamin B12 and B - carotene) and mineral like calcium, magnesium, potassium, phosphorus and copper. It binds nitrogen and produces nitrates and has been used to produce fertilizer in China for over 1000 years. The leaves from Azolla are little, sensitive and comes in different colour (Alalade and lyayi, 2006).

Several research has been carried out on the effect of supplementing Azolla in the diet of broilers, for instance Biplop et al (2002) and Pinkihan , R. W (2013) reported a significant $(P<0.05)$ difference in final live weight and feed conversion ratio of broilers fed with $5 \%$ Azolla meal. Babeker and Bdalbagi (2015) stated that the incorporation of moringa leaves at $50 \%$ with sorghum hay at $4 \%$ significantly increased the weight and some physiological parameters of Sudan Nubian goats. Most of these experiments have clearly shown that Azolla and Moringa are good source of protein, but there is a dearth of information on the dietary supplementation of Azolla on nutrient utilization and blood profile of broilers, therefore, a mixture of Azolla and Moringa will enhance a better performance in birds and reduce feed cost.

Blood analysis gives a clear picture on an animal's physiological status (Adenkola et al, 2004) and can be affected by several factors such as age, species and nutrition (Yeong, 1999; Amakiri et al, 2009; Afolabi et al, 2010). According to Hauptmanova et al (2006) and Abdi-Hachesoo et al (2011) haematological parameters are vital tools in disease diagnosis.

Therefore, this study was conducted to evaluate the growth performance, nutrient utilization and haematological parameters of broiler chickens fed different levels of Azolla-Moringa Oleifera leaf meal.

\section{MATERIALS AND METHODS}

\section{Site of the experiment}

The experiment was carried out at Dan-malafia Farms Ibadan, Oyo State, Nigeria.

\section{Preparation of experimental diets}

Fresh Moringa leaves used for the experimental diets were harvested from Moringa trees in the farm; it is later spread on a concrete floor and allowed to dry for 11 days (air dried). The dried leaves were milled into fine particle size using attrition mill to produce Moringa leaf meal. The Moringa leaf meal was later subjected to proximate analysis as expressed in Table 3.

Fresh Azolla was harvested from the propagation pond within the farm premises and washed thoroughly to remove residues, it was later placed on flat metal trays and sun dried for 5 days until the leaves turns brown and crumbles when squeezed. It was then milled into Azolla powder. The turmeric rhizome (dry roots) were collected from the experimental site, sun-dried for 8 days and milled to produce turmeric powder.

The moringa leaf meal and the Azolla powder were mixed together in ratio $4: 10$ respectively to form moringa leaf meal - turmeric azolla mixture (MLMAZP). The test materials were mixed with together with other ingredients to form four (4) experimental diets at levels of $0,5,10,15 \%$ respectively. The proximate components were determined by the A.O.A.C (1990), 
the basal feed was formulated to meet up with the requirement of broilers according to NRC (1994).

\section{Animals and their management}

One -day old 160 broilers (Arbo-acre) were obtained from a commercial hatchery in Ibadan. The chicks were reared in group and feed for one week before the start of the experiment on a commercial starter feed (adaptation period). At the end of the adaptation period, all chicks were weighed and assigned into four (4) dietary treatment groups; each group was further divided into four replicates each of ten (10) chicks in a completely randomized design (CRD). A deep litter poultry house was used; the house was cleaned and well disinfected before the commencement of the experiment. Vaccines were administered according to the prevailing vaccination schedule in the environment. Feed and water were offered ad-libitum. The light was continuous throughout the experimental period which lasted for 42 days.

\section{Parameters measured}

The initial body weight was recorded at the beginning of the experiment and weekly thereafter, total feed and water consumption, mortality were recorded daily throughout the experimental period.

\section{Nutrient retention trial}

Nutrient retention trial was carried out on the sixth week of the experiment, a known quantity of feed were given per treatment and the faecal output were collected for 3 days and was later subjected to chemical analysis according to AOAC (1990).

\section{Carcass Evaluation}

At the end of the sixth week, four (4) birds were randomly selected per treatment; they were fasted overnight and given only water, weighed and slaughtered. After evisceration, the organs were removed and weighed. The carcass weight, dress weight, weight of the visceral organs and other parts of the birds were also recorded.

\section{Haematological Analysis}

At the $6^{\text {th }}$ week of the experiment, blood samples were collected from the brachial vein of three randomly selected birds per treatment. The blood samples were analyzed for some hematological and serum biochemical parameters; blood samples for hematology were collected into bottles containing Ethylene Diamine Tetra Acetate (EDTA). The hematological parameters such as Pack cell volume (PCV), Red blood cell (RBC), White blood cell (WBC), Haemoglobin concentration $(\mathrm{Hb})$ and absolute counts of neutrophils, lymphocytes, monocytes and eosinophils were computed according to the method of Jain (1986). Mean corpuscular volume (MCV), Mean corpuscular haemoglobin $(\mathrm{MCH})$ and Mean corpuscular haemoglobin concentration (MCHC) were estimated according to the method of Ritchie et al (1994).

\section{Statistical Analysis}

All data collected were subjected to one way Analysis of variance (ANOVA) by Steel and Torrie (1980). Significant means separated by Duncan multiple range test (Duncan, 1955).

Table 1: Composition of experimental (Broiler starter) diets (\%)

\begin{tabular}{|c|c|c|c|c|}
\hline Ingredients & & & & \\
\hline & 1 & 2 & 3 & 4 \\
\hline Maize & 50.00 & 50.00 & 50.00 & 50.00 \\
\hline Soy bean meal & 23.00 & 23.00 & 23.00 & 23.00 \\
\hline Groundnut cake & 15.00 & 15.00 & 15.00 & 15.00 \\
\hline Fish meal (72\%) & 2.00 & 2.00 & 2.00 & 2.00 \\
\hline Bone meal & 3.00 & 3.00 & 3.00 & 3.00 \\
\hline Limestone & 2.00 & 2.00 & 2.00 & 2.00 \\
\hline Lysine & 0.25 & 0.25 & 0.25 & 0.25 \\
\hline Methionine & 0.25 & 0.25 & 0.25 & 0.25 \\
\hline Premix & 0.25 & 0.25 & 0.25 & 0.25 \\
\hline Salt & 0.25 & 0.25 & 0.25 & 0.25 \\
\hline Oil & 3.00 & 3.00 & 3.00 & 3.00 \\
\hline MLMAZP & 0.00 & 5.00 & 10.0 & 15.0 \\
\hline Determined Analvsis & 100.0 & 100.0 & 100.0 & 100.0 \\
\hline Crude protein (\%) & 23.10 & 23.13 & 23.17 & 23.22 \\
\hline Ether extract (\%) & 3.90 & 3.91 & 3.90 & 3.92 \\
\hline Ash (\%) & 6.67 & 6.70 & 6.66 & 6.71 \\
\hline Energy (Kcal/kg) & 3140.64 & 3138.41 & 3130.52 & 3101.05 \\
\hline
\end{tabular}

*Premix supplied per kg diet :- Vit A, 12,000 I.U; Vit E, 5mg; Vit D3, 3000I.U, Vit K, 3mg; Vit B2, 5.5mg; Niacin, 25mg ; Vit B12, $16 \mathrm{mg}$; Choline chloride, 120mg ; Mn, 5.2mg ; Zn, 25mg ; Cu, 2.6g ; Folic acid, 2mg ; Fe, $5 \mathrm{~g}$; Pantothenic acid, 10mg ; Biotin, $30.5 \mathrm{~g}$; Antioxidant, $56 \mathrm{mg}$ 
Table 2: Composition of experimental (Broiler finisher) diets (\%)

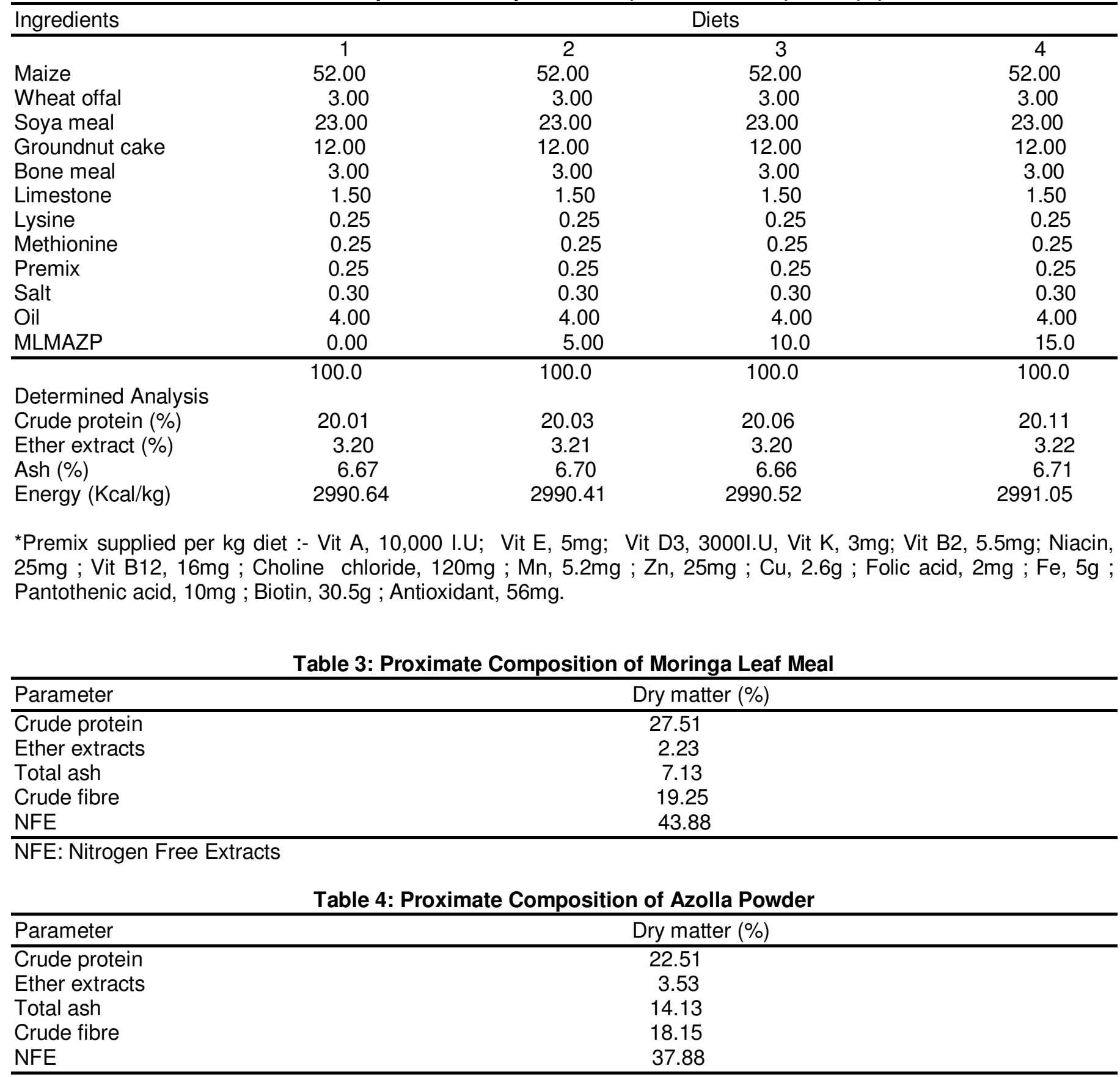

NFE: Nitrogen Free Extracts 
Table 5: Effect of different levels of MLMAZP on the performance of broilers

\begin{tabular}{lrrrrr}
\hline Parameters & \multicolumn{5}{c}{ Diets } \\
\hline Performance (g) & 1 & 2 & 3 & 4 & SEM \\
Number of birds & 40.0 & 40.0 & 40.0 & 40.0 & - \\
Initial live weight (g/bird) & 104.0 & 103.0 & 102.1 & 104.2 & 9.20 \\
Final live weight (g/bird) & $1989.3^{\mathrm{c}}$ & $2190.2^{\mathrm{b}}$ & $2304.1^{\mathrm{b}}$ & $2406.1^{\mathrm{a}}$ & 31.07 \\
Total weight gain (g/bird) & $1885.3^{\mathrm{c}}$ & $2087.2^{\mathrm{b}}$ & $2202.0^{\mathrm{b}}$ & $2301.9^{\mathrm{a}}$ & 11.40 \\
Total feed intake (g/bird) & 3300.7 & 3305.0 & 3330.8 & 3382.4 & 86.12 \\
Feed conversion ratio (FCR) & 1.66 & 1.51 & 1.46 & 1.41 & 0.26 \\
Daily water intake (lit/day) & 18.9 & 23.2 & 23.6 & 23.8 & 1.03 \\
Mortality & 0.00 & 0.00 & 0.00 & 0.00 & - \\
Feed cost /kg & 140.0 & 142.0 & 144.0 & 144.6 & 7.10 \\
\hline
\end{tabular}

abc means different superscript along rows differs significantly at $\mathrm{P}<0.05$

Table 6: Effect of feeding graded levels of MLMAZP on the nutrient retention of broilers

\begin{tabular}{lccccc}
\hline Parameters & \multicolumn{5}{c}{ Diets } \\
\hline Protein retention (\%) & 1 & 2 & 3 & 4 & SEM \\
Fat retention (\%) & $60.08^{\mathrm{a}}$ & $56.01^{\mathrm{b}}$ & $53.11^{\mathrm{c}}$ & $51.17^{\mathrm{c}}$ & 1.67 \\
Fibre retention (\%) & $83.24^{\mathrm{a}}$ & $81.13^{\mathrm{b}}$ & $80.19^{\mathrm{c}}$ & $79.67^{\mathrm{c}}$ & 0.03 \\
\hline
\end{tabular}

abc means different superscript along rows differs significantly at $\mathrm{P}<0.05$

Table 7: Carcass characteristics and relative organ weights of broilers fed MLMAZP

\begin{tabular}{lccccc}
\hline & \multicolumn{4}{c}{ Diets } \\
\hline Parameters & 1 & 2 & 3 & 4 & SEM \\
Final weight $(\mathrm{g})$ & 1989.3 & 2190.2 & 2304.1 & 2406.1 & 24.61 \\
Carcass weight $(\mathrm{g})$ & 1389.3 & 1590.2 & 1704.1 & 1806.1 & 20.11 \\
Dressing percentage & 69.84 & 68.91 & 73.96 & 75.06 & 10.61 \\
Head & 4.10 & 6.21 & 6.47 & 6.82 & 0.15 \\
Neck & 3.11 & 4.13 & 4.23 & 4.33 & 0.11 \\
Thigh & 7.03 & 10.15 & 10.34 & 10.90 & 0.91 \\
Shanks & 4.80 & 7.22 & 7.54 & 7.92 & 1.60 \\
Liver & 1.92 & 2.37 & 2.66 & 2.91 & 0.31 \\
Pancreas & 0.26 & 0.41 & 0.48 & 0.59 & 0.14 \\
Gizzard & 2.07 & 3.11 & 3.14 & 3.17 & 0.21 \\
Proventriculus & 0.47 & 0.73 & 0.71 & 0.79 & 0.17 \\
Intestine (cm) & 131.2 & 155.9 & 166.0 & 168.9 & 6.67 \\
\hline
\end{tabular}

${ }^{\mathrm{abc}}$ means different superscript along rows differs significantly at $\mathrm{P}<0.05$

Table 8: Effect of feeding different levels of MLMAZP on haematological parameters of broilers

\begin{tabular}{lccccc}
\hline Parameters & \multicolumn{5}{c}{ Diets } \\
\hline & 1 & 2 & 3 & 4 & SEM \\
Pack cell volume (\%) & 36.14 & 36.09 & 36.99 & 36.01 & 1.64 \\
Haemoglobin (g/dl) & 11.20 & 11.71 & 11.89 & 11.09 & 0.20 \\
Red blood cell (10)6ml & 4.00 & 4.03 & 4.10 & 4.11 & 0.09 \\
MCV (m ${ }^{3}$ ) & 91.20 & 93.19 & 93.80 & 94.06 & 1.20 \\
MCH (pg) & 31.11 & 31.07 & 32.07 & 31.25 & 0.08 \\
MCHC (\%) & 30.80 & 36.71 & 35.13 & 33.45 & 0.56 \\
White blood cell (10)6mm & 11.77 & 11.80 & 12.08 & 12.11 & 1.87 \\
Neutrophil (\%) & 71.11 & 70.88 & 71.60 & 71.34 & 3.04 \\
Monocytes (\%) & 3.01 & 3.80 & 3.01 & 3.11 & 0.09 \\
Lymphocytes (\%) & 48.77 & 49.09 & 49.11 & 49.87 & 1.66 \\
Eosinophils (\%) & 4.01 & 4.11 & 4.06 & 4.08 & 0.37 \\
\hline
\end{tabular}

abc means different superscript along rows differs significantly at $\mathrm{P}<0.05$

MCV: Mean Corpuscular Volume

$\mathrm{MCH}$ : Mean Corpuscular Haemaoglobin

MCHC: Mean Corpuscular Haemoglobin Concentration 


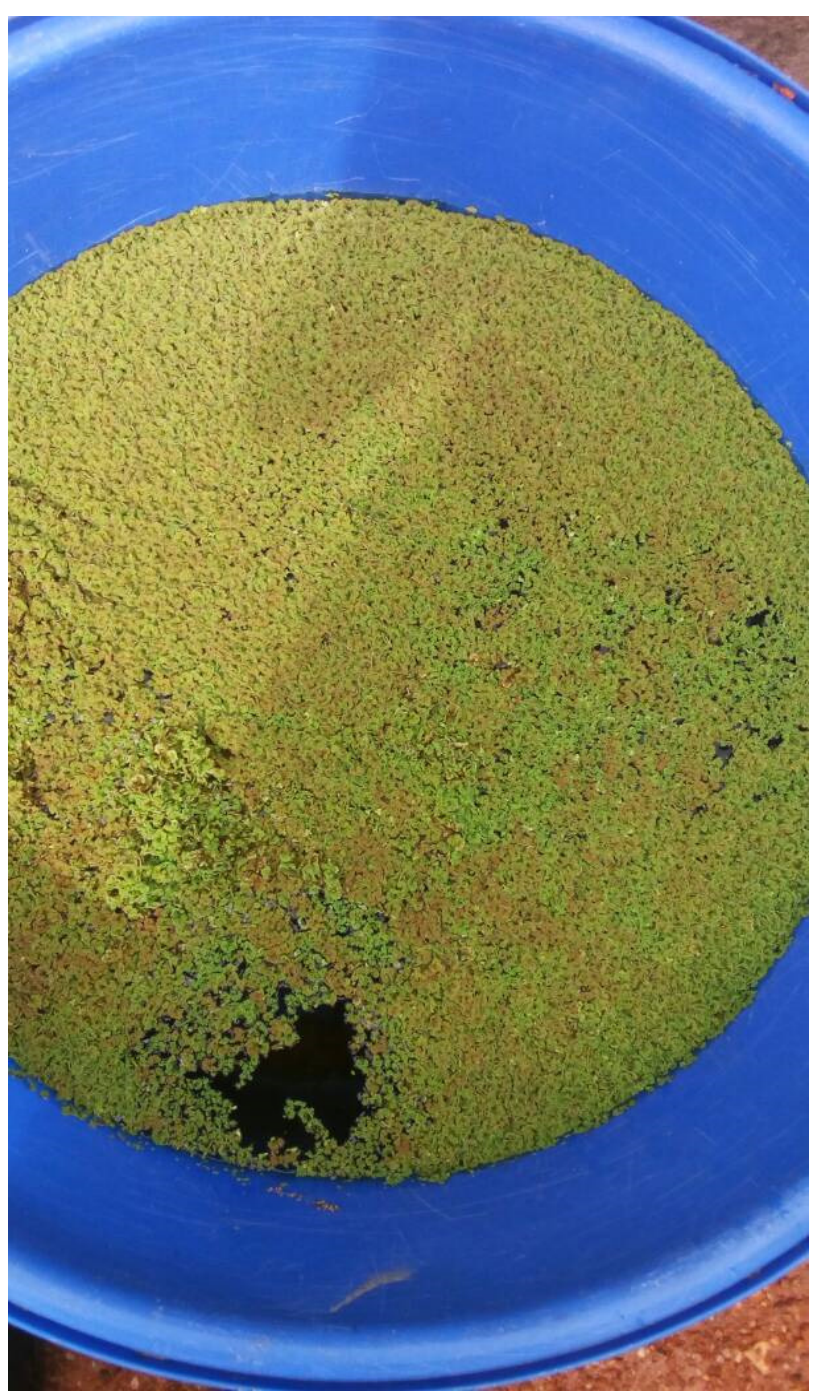

Figure 1: Propagated Azolla 


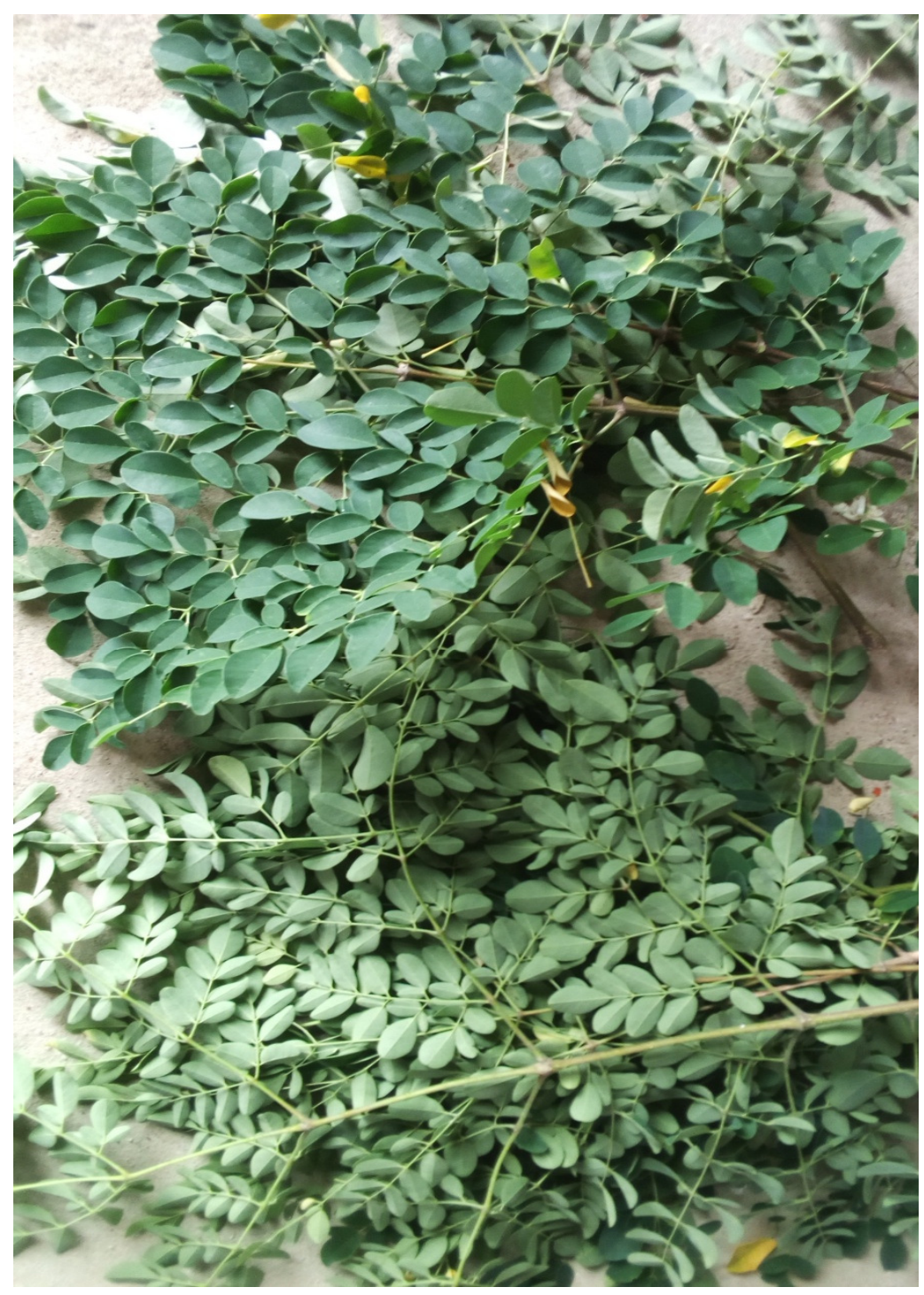

Figure 2: Freshly harvested Moringa leaf 


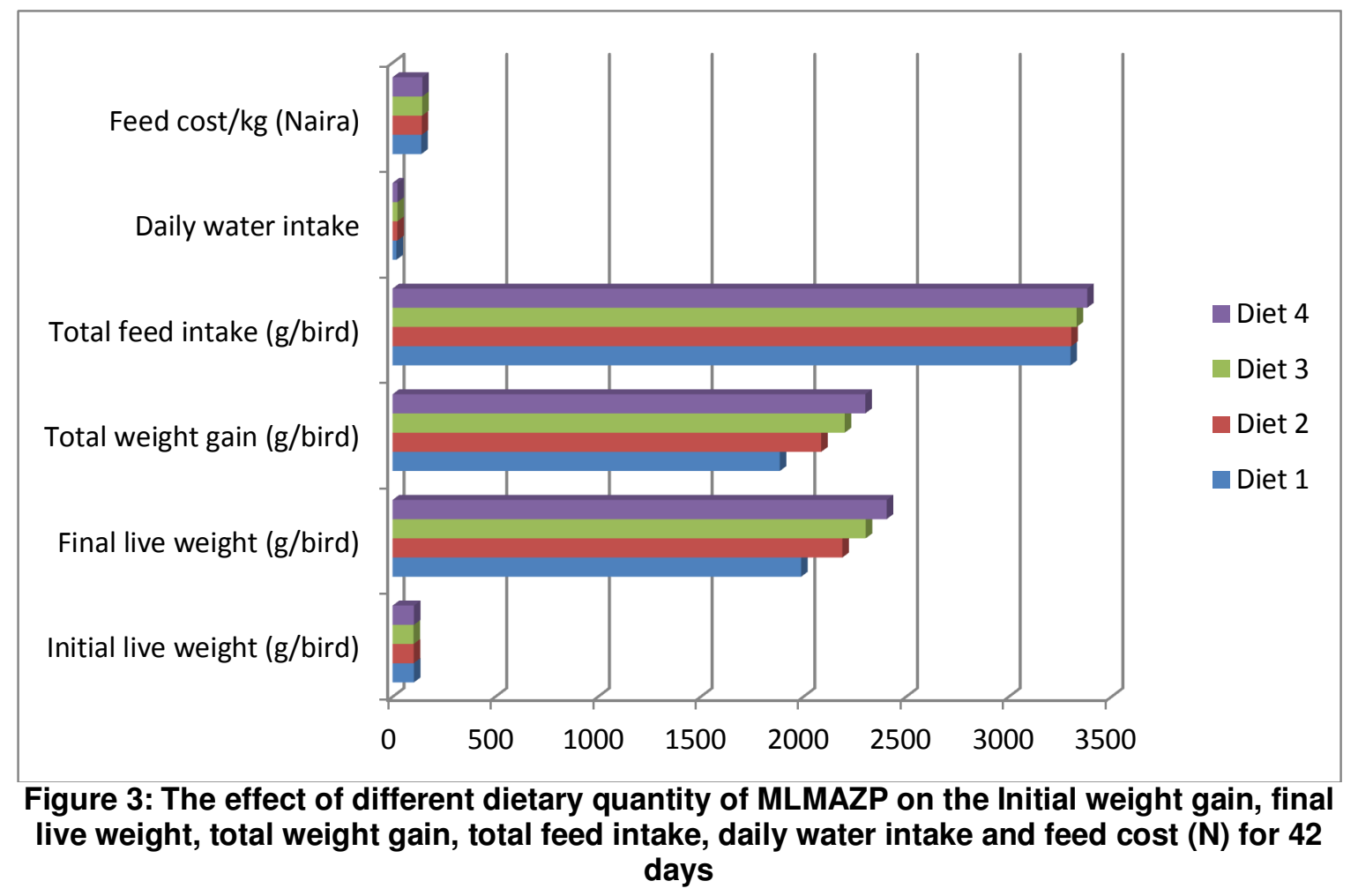

\section{RESULTS}

Table 1 and 2 reveals the composition of experimental diet; it was formulated to meet the nutrients requirements of broilers according to the NRC (1994).

Table 3 shows the proximate composition of Moringa leaf meal (MLM). The proximate components contains $27.51 \%, 19.25 \%, 2.23 \%, 7.13 \%$ and $43.88 \%$ of crude protein, crude fibre, ether extract, ash and nitrogen free extract respectively. Table 4 reveals the proximate composition of Azolla, the proximate components contains $22.51 \%, 3.53 \%, 14.13 \%, 18.15 \%$ and $37.88 \%$ of crude protein, ether extracts, total ash, crude fibre and nitrogen free extract respectively. Table 5 shows the growth performance of broilers, the final live weight ranges between 2406.1 and 1989.3grams. There was a significant difference $(P<0.05)$ among treatment in terms of their final live weight. The total feed intake values obtained are 3300.7, 3305.0, 3330.8 and 3382.4 grams for diet 1,2, 3 and 4 respectively while those of feed conversion ratio are $1.66,1.51,1.46$ and 1.41 respectively for diets $1,2,3$ and 4 respectively. The daily water intake values obtained are 18.9, 23.2, 23.6 and 23.8 (lit/day) for diets $1,2,3$ and 4 respectively while those of feed cost $/ \mathrm{kg}$ are 140.0, 142.0, 144.0 and 144.6 (N) for diets 1, 2, 3 and 4 respectively. No mortality was recorded throughout the experimental period. The final weight, feed conversion ratio and daily water intake were significantly $(P<0.05)$ affected by the dietary inclusion of Azolla -Moringa leaf meal mixture (MLMAZP).

The nutrient retention parameters investigated are presented on Table 6 . Protein retention values are $60.08 \%, 56.01 \%, 53.11 \%$ and $51.17 \%$ for diets $1,2,3$ and 4 respectively while those of fat retention are 83.24 , $81.13,80.19$ and 79.67 (\%) for diets 1, 2, 3 and 4 respectively. The values for fibre retention are $47.34 \%$, $38.97 \%, 34.06 \%$ and $31.88 \%$ for diets $1,2,3$ and 4 respectively. Protein, fat and fibre retention were influenced $(P<0.05)$ by the dietary inclusion of MLMAZP.

The carcass weight and the relative organ weights of broilers fed different levels of MLMAZP are presented in Table 7 . The relative weights of liver, head, shanks, neck, thigh, pancreas, proventriculus, intestine and gizzard fed MLMAZP were significantly different from diet 1 . The dressing percentage values obtained are $69.84 \%, 68.91 \%, 73.96 \%$ and $75.06 \%$ for diets 1,2 , 3 and 4 respectively. The values were significantly $(P<0.05)$ different from each other.

The haematological parameters as influenced by the diets are presented on Table 8 . The pack cell volume (PCV) values obtained are $36.14 \%, 36.09 \%$, $36.99 \%$ and $36.01 \%$ for diets $1,2,3$ and 4 respectively while those of heamoglobin $(\mathrm{Hb})$ are $11.20,11.71,11.89$ and $11.09(\mathrm{~g} / \mathrm{dl})$ for diets $1,2,3$ and 4 respectively. The Red blood cell (RBC) values obtained are 4.00, 4.03, 4.10 and $4.11\left(10^{6} \mathrm{ml}\right)$ for diets $1,2,3$ and 4 respectively. The PCV, $\mathrm{Hb}$ and $\mathrm{RBC}$ values slightly increased from diet 1 to 4 but were not significantly $(P>0.05)$ affected by the dietary inclusion of

MLMAZP. Mean corpuscular volume (MCV) values obtained are 91.20, 93.19, 93.80 and $94.06\left(\mathrm{~m}^{3}\right)$ for diets $1,2,3$ and 4 respectively while those of Mean corpuscular haemoglobin $(\mathrm{MCH})$ are $31.11,31.07,32.07$ and $31.25(\mathrm{pg})$ for diets 1, 2, 3 and 4 respectively. Mean corpuscular haemoglobin concentration $(\mathrm{MCHC})$ values 
obtained are $30.80 \%, 36.71 \%, 35.13 \%$ and $33.45 \%$ for diets 1, 2, 3 and 4 respectively. $\mathrm{MCV}, \mathrm{MCH}$ and $\mathrm{MCHC}$ values were not significantly $(P>0.05)$ influenced by the different inclusion of MLMAZP. White blood cell (WBC) values obtained are $11.17,11.80,12.08,12.11\left(10^{6} \mathrm{ml}\right)$ for diets $1,2,3$ and 4 respectively while those of neutrophils are $71.11 \%, 70.88 \%, 71.60 \%$ and $71.34 \%$ for diets 1, 2, 3 and 4 . The monocytes values obtained are 3.01, 3.80, 3.01 and 3.11 (\%) for diets 1, 2, 3 and 4 respectively while the lymphocytes values obtained are $48.77 \%, 49.09 \%, 49.11 \%$ and $49.87 \%$. WBC, monocytes, neutrophils, lymphocytes and eosinophils values were not significantly $(P>0.05)$ different among the treatments.

\section{DISCUSSION}

The experimental diets clearly shows that Moringa leaf meal and Azolla powder contains significant level of protein, this reflected because the crude protein content of the experimental diet increased slightly as the inclusion of MLMAZP increases, it significantly $(P<0.05)$ affected the final live weight of the birds in all the treatment groups. This shows that the inclusion of MLMAZP across the treatment can support the growth of broilers. Birds fed diet 4 had a better final live weight followed by diet 3,2 and 1 respectively; this could be due to a higher protein content contained in the experimental diet. According to Preston and Leng (1987), the growth rate of an animal is determined by feed intake and digestibility, with feed intake being determined by balance of nutrients especially protein in relation to energy for metabolism. MLMAZP can also be referred to as good unconventional and alternative protein source for birds because it contains more than $20 \%$ protein (NRC, 1994), this report agrees with the findings of Parthasarathy et al (2001) and Shoukat Ara (2015) who reported that broilers fed 5\% Azolla powder had a better final live weight and conversion ratio. Highest feed intake $3382.4 \mathrm{~g} / \mathrm{bird}$ and weight gain $2301.9 \mathrm{~g} / \mathrm{bird}$ were observed in birds fed diet containing $15 \%$ MLMAZP, birds fed 0\% MLMAZP had the lowest value of $3300.7 \mathrm{~g} / \mathrm{bird}$ and $1885.3 \mathrm{~g} / \mathrm{bird}$ respectively and this could be due to the high level of protein in Moringa and Azolla powder. The proximate analysis recorded for Moringa leaf meal and Azolla powder agrees with the findings of Odura et al (2008); Babeker and Bdalbagi (2015); Querubin et al (1986); Basak et al (2002); Alalade and lyayi (2006) and Shoukat et al (2015) but contrary to the reports of Pinkihan, R.W (2013), this could be due to differences in species.

The values of the FCR and daily water intake were significantly $(P<0.05)$ affected with the inclusion of MLMAZP. The daily water intake increased with from diet 1 to 4, this agrees with the report of Alagbe, J.O (2016) when sweet orange peel fruit was used as a replacement for maize in the diet of grass cutters. No mortality was recorded throughout the experimental period; this may be due to proper management, good stock of day old chicks and non deleterious effect of Moringa and Azolla powder. The feed cost were not significantly $(P>0.05)$ affected, this result agrees with the findings of Alagbe, J.O (2017) when matured Polyalthia longifolia leaf was incorporated in the diets of broilers.

Protein retention, fat retention and fibre retention were significantly $(P<0.05)$ influenced by the inclusion of MLMAZP across the treatments, this agrees with the findings of Sola et al (2011) when layers were fed Baobab seed meal but contrary to the reports of Alagbe, J.O (2017) on the inclusion of Polyalthia longifolia meal as phytobiotics compared with antibiotics on the nutrient retention of broilers.

According to Nottidge (1998), the physiological, nutritional and pathological conditions of animals are usually assessed using heamatological and biochemical analysis of their blood. Haematological components, which consists of red blood cell (RBC), white blood cell (WBC), $\mathrm{MCH}, \mathrm{MCV}, \mathrm{MCHC}$ are valuable in monitoring feed toxicity especially feed constituents' that affect the blood as well as health status of animals (Oyawoye and Ogunkunle, 2004).

The values of the RBC were not significantly $(P>0.05)$ affected with the inclusion of MLMAZP, this is a clear indication that there is sufficient oxygen and carbon dioxide in the body of the animal. According to Isaac et al (2013), red blood cell is involved in the transport of oxygen and cabon dioxide in the body. RBC carries carries haemoglobin which reacts in the blood to form oxyhaemoglobin during respiration (Olayemi et al, 2000). This result agrees with the findings of Terzungwe et al (2013) and Olatunji et al (2016) on the physiological responses of rabbits fed graded level of Moringa Oleifera meal and effect of varying levels of Moringa Oleifera meal on performance and blood profile of weaner rabbits respectively. The RBC values falls within the range reported by Ibrahim Albokhadaim (2012); Talebi et al (2005). According to Brown et al (2000) increased RBC values are associated with high quality dietary protein and with disease free animals. The pack cell volume $(P C V)$ values were not significantly affected $(P>0.05)$ by the dietary inclusion of MLMAZP, the values increased from diet 1 to 4 , it is a clear indication that oxygen and nutrients are well absorbed within the animal's body, thus an increased PCV shows a better transportation of oxygen and nutrients. According to Chineke et al (2006) high $P C \vee$ readings shows an increase in the number of $\mathrm{RBC}$ or

reduction in circulating plasma volume. $\mathrm{MCV}, \mathrm{MCH}$ and $\mathrm{MCHC}$ values examined were within the reference range of broilers reported by Polo et al (1992); Abdi-Hachesoo et al (2011).

The WBC, neutrophils, lymphocytes, eosinophils and monocytes were not significantly $(P>0.05)$ influenced by different inclusion of MLMAZP, although the WBC values slightly increased from diet 1 to 4 it is a 
clear indication that more antibodies were produced with the different inclusion of MLMAZP. According to Soetan et al (2013), animals with low WBC are exposed to high risk of disease infection while those with high counts are capable of generating antibodies to fight infection. This agrees with the findings of Omer et al (2014) on the effect of feeding different levels of Moringa leaf meal on the performance and some blood parameters of broilers. Butterworth (1999) also reported that basophils and eosinophils are important effector cells in allergy and host defense responses particularly against parasitic infections.

Relative weights of organs (head, neck, thigh, shank, liver, pancreas, gizzard, proventriculus and intestine) fed MLMAZP were significantly different $(P<0.05)$ from the control diet, no enlargement was observed on the internal organs which signifies that the birds can tolerate MLMAZP without any deleterious effect. According to Madhusadhan et al (1986), anti nutrients causes enlargement in the internal organs of animals. The study also shows that dressing percentage of broilers which ranged from $69.84 \%$ to $75.06 \%$ were significantly $(P>0.05)$ different from each other, this is contrary to the reports of Bolu et al (2009) when dried pawpaw seed was fed to broilers.

\section{CONCLUSION}

It could be concluded that Moringa leaf meal and Azolla powder contains essential nutrients that are needed for the proper growth and development of animals; it does not induce any toxic effect on birds. Most parameters measured viz growth and carcass evaluation showed a significant difference. Therefore the inclusion of MLMAZP at $15 \%$ has no deleterious effect on the performance and health status of broilers.

\section{ACKNOWLEDGEMENT}

The Author is grateful to Pastor Isaac Jideofor, President of the Millionaire Farmers Association for Supplying the Azolla that was used in carrying out the experiment, God bless you Sir.

\section{REFERENCES}

Abdi-Hachesoo., Talebi, B.A and Asri-Rezaei (2011). Comparative study on blood profiles of indigenous and Ross-308 broiler breeders. Global Vet. 7:238241

AOAC, (1990): Association of Official Analytical Chemist Official Method of Analysis $15^{\text {th }}$ Edition Washington, D.C. pages $70 \quad-88$. 3. Asar (2010): Utilization of Corn-cob meal and faba bean straw in growing rabbits diets and their performance, digestibility and economical efficiency. Egypt Poultry Science. 2010; 30: 415-442.

Amaakiri, A.O., Owen, O.J and Jack, D.O (2009). Effects of refined petroleum product (kerosene) flame and fumes on haematological characteristics of broiler chickens. Proc of the $34^{\text {th }}$ Annual conference of the Nig. Soc. Of Anim. Prod 2009: 41-44.

Alagbe, J.O (2016). The nutritional evaluation of sweet orange fruit peel meal (SOFPM) as a replacement for maize in the diet of weaner grass cutters. Scholarly Journal of Agricultural Sciences. May 2016.

Adekola, A.Y., Durutoye, L.A (2004). Haematological study during pre-partum periods in brown savannah does in Zaria, Nigeria. Proc. of the $38^{\text {th }}$ Annual Conf. of the Agric. Society of Nigeria 2004:538-540

Alalade, O.A and lyayi, E. A (2006). Chemical composition and the feeding value of Azolla meal for egg type chicks. Int'l Jou. Of Poult. Sci. 5(2): 137141.

Alagbe, J.O (2017) Effect of dietary inclusion of Polyalthia longifolia leaf meal as phytobiotic compared with antibiotics on the nutrient retention, immune response and serum biochemistry of broiler chicken. Greener Journal of Agricultural sciences Vol 7(3), pp 074-081, May 2017.

Brown, I. R (2000). Clinical care and medicine of pet rabbit. In : Proc. Of the Michigan Veterinary Conf., 49-77.

Bolu, S.A.O., Sola-Ojo, F.E ., Olorunsanya, O.A and Idris, K (2009) Effect of graded levels of dried pawpaw seed on the performance, heamatology , serum biochemistry and carcass evaluation of broiler chicken. Int. Journal of Poultry Sci. 8(9):905-909, 2009.

Biplob, Basak., Ahsan, Habib Pramanik, M.D., Muhammed, Siddigur Rahman.,Sharif Uddin, Tarafdar and Bimol Chandra Roy (2002). Azolla as a feed ingredient in broiler ration. Int'l Journal of Poultry Science 1(1): 29-34.

Babeker, E.A and Bdalbagi, Y.M.A (2015). Effect of feeding different leaves of Moringa Oleifera leaves on performance, haematological and biochemical and some physiological parameters of Sudan Nubian goats. Online Journal of Animal and Feed Research, Vol 5, Issue 2:50-61: Mar 25, 2015.

Butterworth, A.E (1999). Cell mediated damage to helminthes Adv. Parasitol. 23: 143. 
Basak, B., Pramanik, A. H., Rahman, M.S., Taradar, S. $U$ and Roy, B. C (2002). Azolla as feed ingredient in broiler ration. Int'l Jou. Of Poul. Sci. 1:24-29.

Chineke, C.A., Ologun, A.G and Ikeobi, C.O.N (2006). Haematological parameters in rabbit breeds and crosses in humid tropics. Pakistan Journal of Biological Sciences. 9(11), 2101-2106

Chinsoro, Prince (2015). Potential use of baobab seeds in poultry diets, department of livestock and pasture science. Faculty of Science and Agriculture, University of Fort Hare. Pp 52-53.

Duncan, DB (1955) Multiple range and multiple F tests. Biometrics, 11:1-42

fuglie, L (2009). New uses of Moringa studied in Nicaragua (EDN 68): Moringa leaf (2009)

Francis,G., Makkar, H.P.S and Becker. K (2005). Products from little researched plants as aquaculture feed ingredients retrieved febuarary 24, 2005 from http:// www.fao.org/DOCREPIARTICLE /AGRIPPA/55/FN.HTM\# Topofpage

Fadyimu .B ., Bola, H.S and Sina, G.R (2011) Direct feed microbials and their direct impact on the intestinal micro flora and immune system of chickens. Journal of Poultry Science 47:106-114.

Isaac, L.J., Abah, G., Akpan, B and Ekaette, I.U (2013). Haematological properties of different breeds and sexes of rabbits (p.24-27). Proceedings of the $18^{\text {th }}$ Annual Conference of Animal Science Association of Nigeria.

Ibrahim Albokhadaim (2012). Haematological and some biochemical values of indigenous chickens in AlAhsa, Saudi Arabia during summer season. Asian Journal of Poultry Sciences. 6(4):138-145,2012.

Jain, N.C (1986). Schalms veterinary heamatology $4^{\text {th }}$ edition. Lea and Febiger, Philadelpia.USA, pp 149162.1989.

Kakengi, A. M. V., Shen, M.N., Sarwart, S.V and Fujihara, T (2003). Can Moringa be used as protein supplement to ruminant diet? Asian - Australian Journal of Animal Science. 18 (1): 42-47

Madhusadhan, K.T ., Ranesh, H.P., Ogawa, T., Sasoka, T and Singh, N (1986). Detoxification of commercial linseed meal for use in broiler ration. Poult. Sci., 65: 164-171

Maroyi, Alfred (2006). The utilization of Moringa Oleifera in Zimbabawe Preliminary check list of introduced and nationalized plants of Zimbabwe Kirkia.

Odetola, I., Ellis, W.O and Owusu, D (2012). Nutritional potential of two leaf vegetables : Moringa Oleifera and Ipomea batatas leaves, Scientific and Eassy. $3(2): 57-60$.
Opara, C. C (1996) Studies on the use of Alchornia ordifolia leaf meal as feed ingredient in poultry diets. M.Sc thesis, federal University of technology, Owerri, Nigeria. Pp 150-159.

Omole, A.J., Ogunleke, F.O., Kehinde, A.S and Popoola, Y.A (2011). Small and Medium Scale Grass cutter Farming. Green choice Agric Publication. Pages 1-5.

Olatunji, A.K.., Alagbe, J.O and Hammed, M.A (2016). Effect of varying levels of Moringa Oleifera meal on performance and blood profile of weaner rabbits. International Journal of Science and Research, ISSN (online): 2319-7064.

Ogunsanmi, A.O., Akpavie, S.O and Anosa, V.O (2002). Serum biochemical changes in West Africa dwarf sheep experimentally infected with Trypanosoma brucei. Rev. Elev. Med. Vet. Pays. Trop. 47(2):195

Oyawoye, B.M and Ogunkunle, H.N (2004). Biochemical and haematological reference values in normal experimental animals Pages 212-218. New York : Masson.

Olayemi, F.O., Farotomi, J.O and Fagbohun, O.A (2000). Haematology of the West Africa dwarf sheep under two different management systems in Nigeria. African Journal of Biomedical Research 3(2), 197198.

Omer, M.E and Hyder, E.A (2014) The effect of feeding different levels of Moringa Oleifera leaf meal on the performance and some blood parameters of broilers, International Journal of Science and Research, ISSN (online) 2319-7064, Impact factor (2014):5.611.

Pinkihan, R.W (2013). Feeding value of Azolla (Azolla $\mathrm{sp)}$ meal in broiler diets. Open Science Repository Agriculture. Online (open access) e70081987, doi :10.7392/openaccess. 70081987.

Polo, F..J., Celdran, J. F, Peinado, V.I., Viscor, G and Palomeque, J (1992). Haematological values of four species of birds of prey. Condor, 94:1007-1013.

Pannaeker. S (1988) Azolla as a livestock and poultry feed. Livestock Adviser 13:22-26

Preston, T.R., Leng, R.A (1987). Matching ruminant production system with available resources in the tropics and sub- tropics. Penambul Books Limited: Armidale NSW, Australia

Parthasarathy, R., Kadivel, R and Kathaperumal, V (2001). Chemical evaluation of Azolla as a Poultry feed ingredients. Cheiron 30:24-26.

Querubin, L. G., Alcantara, P.F and Luis, E.S (1986). Chemical composition and feeding value of Azolla in broiler ration. Philippines Jou. Of Vet and Anim. Sci 13:46. 
Ritchie, B.W., Harrison, J.G and Harrison, R.L (1994). Avian Medicine Wingers Publishing Inc. Florida.

Soetan, K.O., Akinrinde, A.S and AJibade T.O (2013).

Preliminary studies on the haematological parameters of cockerels fed raw and processed guinea corn (Sorghum bicolor) Pg 42-52. Proceedings of $38^{\text {th }}$ Annual Conference of Nigerian Society of Animal Production.

Steel, R. G.D and Torrie, J.H (1980). Principles and procedures of sataistics. A biometrical approach, $2^{\text {nd }}$ edn McGraw-Hill Book Coy. NY. USA.

Shoukat, Ara., S. Adil., M.T. Banday and Manzoor, A Khan (2015). Feeding potential of Aquatic fern Azolla in broiler chicken ration. Jour. Poult. Sci and Tech. 16-19.

Talebi, A., Asri-Rezaei, S., Rozeh-Chai, R and Sahraei, $R$ (2005). Comparative studies on haematological values of broiler strains ( Ross, Cobb, Arbo-acres and Arian). Int'l Journal of Poultry Sci., 4:573-579.

Nottidge, H.O., Taiwo, V.O and Ogunsanmi, A.O (1999). Haematological and serum analysis of cat in Nigeria. Trop. Vet., 17:9.

National Research Council (1991). Microlivestock : Little known small animals with promising economic future XVII - 449pp. National Academy Press, Washington D.C.

Terzungwe, A., Adakole, H., Abu and Lois K. I (2013) Physiological responses of rabbits fed graded levels of Moringa Oleifera leaf meal (MOLM): some aspects of haematology and serum chemistry. Archives of Applied Science Research, 2013, 5(2): 172-176.

Yeong, S. W (1999). Effect of dietary protein on growth performance of village chicken. Proc. National IRPA Seminar Agric Sector, 2519-2520. 